\title{
MOŠKO TELEŠENJE: OD TEHNIKE DO PLESA
}

Ključne besede: telo, telešenje, moški, moškosti, šport, tehnika, odrski ples

\section{Uvod}

Moje zanimanje za moško telešenje ${ }^{1}$ izhaja iz vpletenosti v svet odrskega plesa, kjer sem bila nemalokrat priča kulturnim predstavam o moškosti, ki moškemu spolu onemogočajo vstop v plesno dvorano. Kaj takšnega si ne bi mogli niti predstavljati, če bi se ta trenutek znašli v 17. stoletju, ko so se v dvornih baletih postavljale predvsem kraljeve moške noge. Zakaj se danes moškim, ki plešejo, v širokem diskurzu tako rado odvzame moškost? Ko sem se lotila študija zgodovine odrskega plesa in zgodovine oblikovanja spolov in spolnosti na zahodu, nisem mogla mimo telesnih praks, ki moškim danes zagotavljajo priznanje te prestižnostne dihotomne identitete. $\mathrm{V}$ pričujočem članku se bom posvetila predvsem telesnim praksam, ki zelo jasno sodelujejo $v$ nenehni gradnji hegemonske moškosti ${ }^{2}$ (praksam športa in tehnike), za tem sledi pa še pogled v plesno areno, kjer bom na kratko predstavila zgodovino oblikovanja predsodkov do moškega plesanja. Kak-

1 Termin »telešenje« izhaja iz angleškega koncepta poimenovanega embodiment, ki ga je v slovenščini, sicer pod prevodom »telesenje«, natančneje že obdelal Rajko Muršič (2006). Koncept bom v večji meri uporabljala in ponazarjala v nadaljevanju, za zdaj pa naj samo povem, da označuje gradnjo in internalizacijo družbenih razmerij oziroma identitet skozi telesne prakse.

2 "Hegemonsko moškost bi lahko definirali kot konfiguracijo spol(izira)nih praks, ki telesi trenutno sprejet odgovor na problem legitimacije patriarhata, ki zagotavlja /.../ dominantno pozicijo moških in podrejenost žensk.« (Connell, 1995, 77) 
šno telesenje se odvija $\mathrm{v}$ plesnem svetu, bom skušala na kratko ponazoriti s fragmenti iz svojih opazovalnih dni v SNG Opera in balet Ljubljana. ${ }^{3}$

Da bo pričujoče pisanje lažje zdrknilo po možganskih sinapsah, si bomo najprej ogledali popis izvenbaletnih materializacij spoliziranega ${ }^{4}$ sveta.

\section{O kulturi in naravi spola}

Avstralski sociolog Rob W. Connell, eden vodilnih raziskovalcev in teoretikov na področju raziskav spola in spolnosti v sodobnosti, svojo knjigo Spol (Gender, 2002) začenja z naslednjimi podatki: $93 \%$ ministrskih mest v svetovnem korpusu parlamentov zasedajo moški; med letoma 1987 in 1996 se je v Avstraliji zgodilo 29 večkratnih umorov s strelnim orožjem in vse so zagrešili moški; moški so večinski posedovalci orožja v svetu; v sodobnih družbah večino dela doma in skrbi za otroka opravijo ženske; kljub enakemu številu delovnih ur, ženske zaslužijo manj - izračun svetovne statistike pravi, da povprečna plača ženske dosega $56 \%$ moške plače. Kot nekje sarkastično sikne Connell: ženske so pač z Venere, moški pa z Marsa. A to prepričanje, vera $v$ naravno determinacijo zgoraj omenjene slike, še zdaleč ni samo šala. Za obstoječi družbeni (spolni) red so se vedno našle zagovorniške teorije.

Po vzoru iz 19. stoletja, ko je Darwin vzpostavil teorijo o evolucijskem razvoju vrst, se je na zahodu iz področjih biologije, psihologije in fizične antropologije razvila sociobiološka znanost, ki je obstoječi družbeni sistem opravičila s konceptom boja za preživetje (beri - patriarhat je najuspešnejša rešitev). Čeprav se je v času od njenih začetkov pa do danes že marsikaj spremenilo (o zgodovini sociobiologije, njenih predhodnih stebrih in o sodobni teoretski pluralnosti si preberi v Laland in Brown, 2002), raziskave, ki dokazujejo naravno pogojenost spolno specifičnega vedenja, še vedno najdejo pot do raziskovalskega denarja. Tovrstne raziskave se v veliki meri osredotočajo na analiziranje vedenja človeku bližnjih primatov - opic, kjer se navadno do-

3 Ljubljanski baletni ansambel sem obiskovala med oktobrom 2005 in marcem 2006. Etnografijo s tega obdobja si je moč prebrati v Pezdir (2008).

4 Slovenska beseda »spol« že sama denotira polovičnost (Snoj, 1997, 597). S spoliziranim svetom imam v mislih predvsem dihotomno urejene družbene odnose. 
kaže agresivnost in tekmovalnost samcev v nasprotju z materinskim gonom pri samicah. Kot piše Susan Sperling, so takšne raziskave, ki so navadno tudi zelo nekonsistentnega in redukcionističnega karakterja, predvsem preslikave zahodne dimorfične miselnosti na nekaj, kar je po propadu kolonialnih imperijev zamenjalo mesta plemenskih divjakov. Kot nekoč prebivalci Tretjega sveta, danes naši sodobniki - opice - služijo ideji o (našem) velenapredku. Kot pravi Sperlingova, tovrstne raziskave vedno zaobidejo ogromno vedenjsko raznovrstnost obravnavane primatske vrste, hkrati pa zamisel evolucije kot stalne proizvajalke najboljših rešitev ignorira druge pomembne evolucijske faktorje, kot so lahko: naključnost procesa, filogenetska inercija, okoljska sprememba in seveda naključna narava mutacij (Sperling, 1997).

Poleg živali se je v »naravni« razlagi spol(ar)iziranosti zahodne družbe seveda znašlo tudi človeško telo. Telo kot proizvod naravnih zakonov in kot »stroj« za proizvajanje družbene urejenosti. Connell piše, da se je tudi na tem zagovorniškem polju, ki je v preteklosti velikokrat uspešno rušilo prizadevanja feminizma (kot pri primeru evolucionizma), ohranila ideologija 19. stoletja, ki nam jo danes posredujejo z osveženimi znanstvenimi koncepti: moško »fizično (pre)moč« (kot vzročnico moške družbene dominacije) je pač zamenjal testosteron - hormon tekmovalnosti, agresije in dominantnosti (gl. Connell, 2002, 31).

Čeprav so biološke (naravne) razlage dimorfnosti kulturnega življenja danes na zahodu kar popularno čtivo (sploh po političnem premiku v desno v devetdesetih), na srečo obstaja znanje, ki esencialistično spolno sliko postavlja pod vprašaj. $\mathrm{V}$ pomembni meri to znanje prihaja iz popisov in orisov družb, ki nimajo takšnih sorodstvenih, spolnih in spolnostnih konceptov, kot jih ima naša (iz kulturne oziroma socialne antropologije), hkrati pa se idejo o primordialnosti spolne identitete močno trga že od takrat, ko je na sceno stopila psihoanaliza.

Freud je bil tisti, ki je odraslo spolnost in kulturni spol pripisal dolgemu in konfliktnemu konstrukcijskemu procesu. O družbenem oblikovanju posameznikove identitete je pisal že v začetku 20. stoletja, je pa njegova metoda do danes doživela precej različnih interpretacij in rab. Znašla se je tako v normalizacijskih kleščah (psihoanalitiki so postali specialisti za zdravljenje 
družbeno nesprejemljivih »patologij« - tudi homoseksualnosti), ${ }^{5}$ po drugi strani je pa njeno feministično branje $\mathrm{v}$ sedemdesetih pomembno prispevalo k naziranju, ki je kulturni spol ločilo od biološkega. Biološki spol (sex) je postal označevalec različnosti med moško in žensko »človeško živaljo«, kulturni spol (gender) pa je zaobsegel polje družbenosti, torej razliko med moškimi in ženskimi »vlogami« in moškimi in ženskimi »osebnostmi«.

Zamisel o ločevanju kulturnega in biološkega spola se je sprva zdela revolucionarna. Postala je močna in popularna konkurenca verovanju $\mathrm{v}$ naravni izvor razlik in torej pomembna odskočna deska za razmišljanje o vedenjskih in organizacijskih spremembah. Connell danes komentira, da je bila verjetno tako dobro sprejeta zato, ker je ustrezala stari zahodni dihotomiji »telo/um« (ki jo, bom dodala jaz, naša družba še vedno močno živi). A spolne vloge - najpogostejši termin za označevanje kulturnega spola $\mathrm{v}$ sedemdesetih in osemdesetih - so imele žal nekaj pomanjkljivosti. V večini primerov niso bile sposobne razložiti, zakaj je ena stran te različnosti (moška stran) konstantno cenjena bolj, kot druga, poleg tega pa so, kot pravi Connell, spolne vloge vseeno predstavljale kulturni izbor na biološki različnosti, kar je še vedno favoriziralo biološkost. In reproduciralo spolno dihotomijo - ki, po teoriji Gayle Rubin (1997), vzdržuje žensko podrejenost v družbah. Naj se sama za primer spomnim nordijskih držav, kjer je feminizem $\mathrm{v}$ šestdesetih vstopil v uradno državno politiko in sta se moška in ženska spolna vloga tudi zelo javno redefinirali; kot o primeru Švedske piše Marie Nordberg (2003), tam moška dominanca (pa kakorkoli nove moške vloge kažejo integracijo »ženskih karakteristik«) o(b)staja še danes.

Smer v akademskem pogledu na spol(ar)iziranost sveta, ki je telesu dokončno odvzela določevalni primat (hkrati pa ga postavila "na ogled«), je tista, ki se je odločila slediti prelomnemu kanonu Michela Foucaulta. Foucaultove analize objektivacij, »ki človeška bitja pretvorijo v subjekte« (Foucault po Dolar, 1991, vii), so poststrukturalističnim raziskavam spola in spolnosti odprle oči za tehnike discipliniranja in nadzorovanja teles, ki diskurze o spolu in spolnosti pretvarjajo v obstoječo materialnost. Ko sta telo in identiteta postala platno za diskurzivno slikarsko izživljanje, so raziskave spola in spolnosti pod lupo postavile institucije in njihovo disci-

5 V klinični rabi se je psihoanaliza znašla predvsem $\mathrm{z}$ vstopom na sever ameriškega kontinenta (Rubin, 1997, 44-45). 
plinatorno delovanje - zelo pogosto npr. šolo, šport in medicino, včasih pa tudi tako "neoprijemljiv« diskurz, kot je lahko "romantična ljubezen« (glej npr. Redman, 2001). Foucaultovi feministični bralci in bralke so velikanovo delo nadgradili; kot pravi Connell, je sam Foucault v svojem opusu pač kompletno spregledal kulturni spol. Čeprav so njegova dela po večini analize moških v maskuliniziranih poklicih (Connell, 2002, 37).

»Kategorija 'biološkega spola' je že v začetku normativna, je, kar je Foucault imenoval 'regulatorni ideal'. Potemtakem 'biološki spol' ne le funkcionira kot norma, pač pa hkrati zaseda del regulatorne prakse, ki producira telesa, katerim vlada, katerega regulativna moč torej postane jasna kot način produktivne oblasti, « je po svoje že omenjeno ubesedila tudi Judith Butler $(1997,531)$. Nadvse citirana sodobna avtorica s področja raziskav spola in spolnosti, ki sicer močno poudarja vlogo vsakodnevne performativnosti, s katero se materializirajo kategorije (katerih meje se konstituirajo na izključitvi; kategorija dobi pomen šele na njenem »neobstoju«, na določitvi kategorije "zunaj«), ${ }^{6}$ žal v veliki meri pozablja na tisto, na kar se nanašajo analizirani označevalci. Kot za poststrukturalistično pisanje nasploh ugotavlja Connell, označevalec - telo - v teh delih včasih kar izgine, večinoma pa pretirano poudarjajo njegovo ubogljivost. To (ponovno) vodi v precej parcialno interpretacijo spolne in spolnostne problematike, je prepričan Connell: telesa lahko namreč v disciplinskih režimih sodelujejo; ne zato, ker so ubogljiva, pač pa zato, ker so aktivna. Ker iščejo užitek, spremembo, izkušnjo. Connell (2002) dialoškost med telesom in diskurzom imenuje kot »telesno-refleksivne prakse«(body-reflexive practices). In ker mi ta koncept predstavlja koristno orodje tako za razumevanje kot interpretiranje spola in spolizirane družbe, se bom ob njem še malce ustavila.

\section{Tvornost telesa in kulturni spol}

$\mathrm{V}$ telesno-refleksivnih praksah teles se manifestirajo družbeni procesi in zgodovina, vendar pri tem telesa ne nehajo biti telesa. Connell v svoji knjigi

6 Na tovrstni strukturalni strategiji sloni že delo Monique Wittig (1997): kategorija »ženska« ima npr. smisel samo v opoziciji $\mathrm{z}$ »moškim«, torej ženska v lezbičnem odnosu ne obstaja. 
Moškosti (Conell, 1995) predstavlja kar nekaj etnografskih primerov, ki jasno kažejo, kako pomembne so lahko telesne izkušnje v posameznih življenjih. V dveh primerih npr. predstavi moška, ki sta zaradi specifičnih telesnih reakcij $\mathrm{v}$ spolnih izkušnjah (v reakciji s specifičnim kulturnim razumevanjem leteh) svoje spolno poželenje preusmerila iz žensk na moške, v enem pa športnika, katerega celotno psihološko in družabno življenje se vrti okoli počutja in stanja njegovega lastnega telesa (prav tam, 60-64): »Telesa premorejo tvornost (agency) in telesa so družbeno konstruirana. Biološka in družbena analiza ne moreta biti odrezani ena od druge /... / (Conell, 2002, 47; kurziv po avtorju). Proces, kjer so telesa tako objekti kot tvorci, Connell v skladu s sodobnimi trendi imenuje tudi »družbeno telešenje« (social embodiment).

Seveda telešenje, ki zadeva kategorijo spola, ni katerokoli telešenje. »Kulturni spol se nanaša na telesne strukture in procese človeške reprodukcije. Te strukture in procesi ne konstituirajo 'biološke osnove', naravnega mehanizma, ki ima družbene učinke. Rajši konstituirajo areno, telesni kraj, kjer se nekaj družbenega zgodi. Med stvarmi, ki se tam zgodijo, je tudi kreacija kulturnih kategorij 'ženske' in 'moški' (in drugih spolnih kategorij, ki jih izriše specifična družba). Sam bom to imenoval za reprodukcijsko areno v družbenem življenju.« (Connell, 2002, 48; kurziv po avtorju.) Kategorije, ki vznikajo iz in okoli te reprodukcijske arene, so seveda relacijskega značaja (Connell, 2002, 54).

Connell dojema (kulturni) spol v relacijah. V knjigi Spol predstavi štiri relacijska polja, skozi katera ga lahko po njegovem mislimo: relacije moči (oblasti), produkcijske, čustvene in simbolne relacije (Connell, 2002, 5868). Odnosi ustvarjajo strukturo (npr. patriarhalno), struktura pa vzpostavlja prakse. Vendar: ker praksa že po definiciji pomeni spremembo (ker producira nekaj, s čimer ni začela) ${ }^{7}$ in ker se odnosi vzdržujejo pri življenju

7 Svojo "pripadnost « praksi si je Connell oblikoval predvsem z branjem Sartrovih del (glej Connell, 1982) in del nekaterih neomarksističnih piscev (npr. Karla Kosika) ter »jugoslovanske šole prakse«. V intervjuju z Lahoucinom Ouzganom in Danielom Colemanom je na vprašanja, zakaj ne sodeluje v splošni moderni rabi koncepta »peformativnosti«, odgovoril: »Ideja performativnosti prihaja od angleškega filozofa govornih dejanj J. L. Austina, ki je opozoril na kategorijo izrazov, ki niso poročila o nečem, pač pa nekaj dosežejo skozi samo dejanje govora. Austin daje za primer duhovnikovo izreko: 'Zdaj vaju razglašam za moža in ženo,' na poroki. V spolu je malo tega, ampak hudičevo veliko spol(izira)nih praks nima nič skupnega s performativnostjo. Npr. spolizirano delo, dejanja nasilja, raba moči/oblasti in velik spekter seksualnih praks.« (http://social.chass.ncsu.edu/jouvert/v2il/Connell.htm). 
prav s prakso (katere del je telesna tvornost), se mora celoten družbeni red znova in znova popolnoma rekonstituirati. Kar se seveda godi tudi spolu.

Spol je vedno interakcijsko delovanje - sta v prelomnem članku Izdelovanje spola ('Doing Gender') leta 1987 zapisala Candace West in Don Zimmerman. Spol se dela. Moškost in ženskost sta "projekta« (si Connell termin sposoja od Sartra $(2002,81)$ ), sta vzorca, ki se usmerjata iz sedanjosti $\mathrm{v}$ prihodnost, kar obenem ne poteka enodimenzionalno in nekonfliktno. Velika raznolikost znotraj vzorcev moškosti in ženskosti, ki je evidentna $\mathrm{v}$ rezultatih raziskav spola in spolnosti, govori o veliko različnih načinih prakticiranja spola, o raznolikih procesih spolnega telešenja, torej. Spol ima poleg sedanjosti in prihodnosti tudi preteklost. Ki pa je v kolonizacijskem prostoru evropskih jezikov ... specifična. ${ }^{8}$

\section{Telo in hegemonska moškost}

Čas, ko se je zahodno določanje in legitimiranje spolnih razlik z religije preneslo na biološko znanost, sovpada s časom, ko sta se spola znašla $\mathrm{v}$ opoziciji in se je telo ogrnilo $\mathrm{z}$ metaforo stroja. Ideja naprave, ki jo je $\mathrm{v}$ totalnosti rodila narava, njena naloga pa naj bi bila od razuma in čustev oddaljeno mehansko funkcioniranje, še danes močno odmeva po hegemonskem dojemanju telesa. Tega ne smemo pozabiti, saj je hegemonsko v družbi enako hegemonskemu med moško populacijo. Telesenje moškega hegemonskega pa Connell povezuje s telesenjem kompetence za pozicijo moči v družbi:

"Menim, da moramo ob povezanju konstruiranja moškosti s strukturami družbene moči v patriarhatu veliko resneje pristopiti h kombinaciji, ki se pojavlja v šolskem športu dečkov, $v$ fizičnem delu in $v$ kultnih fantazijah telesne perfekcije: h kombinaciji moči in veščine. /.../ Biti moški dobesedno pomeni utelešati silo, utelešati kompetenco.«(Connell po Jefferson, 1998, 80.)

8 O zgodovini oblikovanja dihotomnih spolov in $\mathrm{z}$ njima povezane heteronormativnosti si je moč ustvariti sliko preko del Michela Foucaulta (1993; 1998 in 2000) in v zborniku The Gender/Sexuality Reader (1997). 
V skladu s tem, kar sem o spolnih kategorijah zapisala pod prejšnjim naslovom, se telesenje hegemonske moškosti (moči oziroma »kompetence«) seveda lahko kaže tako $\mathrm{v}$ mrkih pogledih, steroidnem napihovanju mišic kot pri šarmiranju z oprijetimi hlačkami, vendar moram hkrati opozoriti, da $\mathrm{v}$ »ženstvenejših « praksah moških vedno obstaja tudi meja, ki moškega še vedno ločuje od popolne ženskosti. V nadaljevanju se bom najprej posvetila telešenju v tistih arenah, za katere bi težko rekli, da so moškega kdajkoli oropale njegove moške kompetentnosti (izbor področij se glasi: mišice in tehnika), kasneje pa sledi pogled na rob »ženstvenejših « praks moških.

\section{Športna instrumentalnost mišičnih utripov}

Telesna dejavnost, ki so jo v zgodovini moderne dobe vztrajno promovirali kot zagotoviteljico "prave« moškosti (kot zdravilo proti »poženščenosti« moških ${ }^{9}$ ter tudi proti homoseksualnosti ${ }^{10}$ ), je dejavnost, imenovana šport. Kljub temu, da si mehansko dojemanje telesa pri njegovi promociji samo močno kontradiktira ( $\mathrm{v}$ videnju moškosti kot naravnega stanja in hkratnemu zagotavljanju, da so športne prakse tiste, ki stanje omogočajo), šport na zahodu vztrajno nadgrajuje svojo hegemonijo na področju gradnje in dojemanja moškosti.

Kar določa šport, niso toliko specifični telesni gibi, kot kontekst, v katerem se ti gibi dogajajo (Adams, 2005, 79). Omenjeni »kontekst« je podmazan $s$ tradicijo zahodnih nacionalizmov in s pridigo meščanske spodobnosti (po Mosse, 2005) - kar sta svetova, ki sta se uspešno utelesila v starejši podobi grškega atletskega lepotca. Evropski nacionalizmi so se v 19. stoletju na grške atletske vzore obrnili zato, ker si je obnovljeni družbeni (patriarhalni) sistem tako lahko pridobil patino »večnosti« (ki je, jasno, koristila legitimaciji njegovih partikularnosti), vendar pa je potrebno ob tem povedati tudi

9 »Poženščenost«, proti kateri so se v 19. stoletju borili britanski vzgojitelji bodoče moške elite, takrat še ni nujno asociirala na homoseksualnost, kot se je zgodilo po sojenju Oscarju Wildu. Lastnost je dostikrat prej pomenila mehkost, šibkost in preveliko druženja z ženskami - tudi v seksualnem smislu (Adams, 2005, 71).

10 Za tovrstne "milejše« ideje v nacističnem pristopanju do homoseksualnosti glej Mosse $(2005,253)$. 
to, da je atletsko telo ob prilagoditvi na moderni spolni trg izgubilo na svoji (homo)erotičnosti. Zahod je občudovanje moške lepote postavil v sfere nadčutnega in domoljubnega užitka (kolikor je to seveda mogoče). Moško telo - močno in vešče - je postalo poosebljenje nacionalnega duha, moške dominacije in seksualne čistosti, torej ni presenetljivo, da so športne aktivnosti - aktivnosti, kjer so se ta super-nadčutna telesa udejstvovala - promovirali kot prakse za telešenje nacionalne pripadnosti, zdravja in - moškosti.

Skozi športne aktivnosti so se fantje in mladi moški začeli učiti, kako zavreti čustva, kako postati močni in trd(n)i, kako sodelovati z drugimi moškimi in seveda, kako telo uporabljati instrumentalno - ne (samo)izrazno. Disciplina in trud timskih športov sta bila kot ustvarjena za telesenje spodobnih pripadnikov svojih (navadno visokih in srednjih) razredov (Adams, 2005, 71).

„Šport moškim ponuja idealno sredstvo za razvoj in izvedbo tradicionalnih moških kvalitet, vključno z oblastjo, močjo in nasiljem, medtem ko zavrača tradicionalno pripisane ženske vrednote.« (Hargreaves po Pappas, McKenry in Skilken Catlett, 2004, 293)

Da so ženske $k$ športu prišle pozno in ob tem požele manj blišča in slave, lahko preseneti malokoga. Kot je pokazala Nancy Chodorow (1974; 1997), se morajo v spolno dihotomiziranih okoljih moški pač oddaljiti od prve identifikacijske točke, ki jim predstavlja varnost, skrb in povezanost (od predojdipske navezanosti na mater), kar pomeni, da se morajo obrniti v njeno nasprotje. Šport se $s$ kanaliziranjem nasilnih impulzov (Jefferson, 1998) in celo s spodbujanjem tovrstnega vedenja (Pappas, McKenry in Skilken Catlett, 2004), idealno ujema s protesti hegemonske moškosti. ${ }^{11}$

11 Uporabljam Adlerjev (1989) koncept moškostnega protesta. Der männliche Protest (http:// $w w w$.bruehlmeier.info/adler.htm), ki ga v angleščini prevajajo kot masculine protest (Connell, 1995, 16), v srbskem jeziku prevajajo kot muški protest (Adler, 1989, 70) in v slovenskem kot moški protest (http://www.beepworld.de/members79/izbran/adler.htm). Sama uporabljam besedno zvezo "protest moškosti«, saj je bistvo koncepta označevanje pojava, ki ga živijo tako moški kot ženske in se izogiba zaverovanosti v biološko dihotomnost družbe. Adler je s protestom mislil predvsem na borbo za dokazovanje osebnostnih lastnosti, ki jim družba pripisuje višji status, na splošno pa jih prisojamo v moško posest. Protest ni zgolj »moški«, saj ga velikokrat izvedejo prav t. i. moški, katerih »moškost« se postavlja pod vprašaj. Adler je moškostni protest sprva prepoznaval pri ženskah, ki so se odpravile po »moški« poti (se udejstvovale na »moških« interesnih področjih, živele samostojno) oziroma pri tistih, ki so 
Potreba po dokazovanju borbene in agresivne moškosti velikokrat preglasi fair play, ki velja za spodobni znak »športnega obnašanja « (kar sicer potrjuje notranjo kontradiktivnost športne arene in hegemonske moškosti z njo), s čimer pa se med športnimi panogami samimi ustvarja pomembna razlika $\mathrm{v} »$ možatosti« početja, ki, jasno, pomeni tudi razliko v splošni popularnosti in podpori panog s strani družbe.

Pri večini skupinskih športov in športov, kjer »nasprotujoča si« tekmovalca nastopata v neposredni konfrontaciji, »borbeni duh « oziroma sposobnost »upati si«, mimogrede preglasi telesno disponiranost in izurjenost. ${ }^{12}$ Upati si prenesti bolečino, celo zadati bolečino - so komunikacijske kvalitete, ki jih spodbujajo in telesijo najmožatejši športi (npr. boks - gl. Jefferson, 1998, 83). Telesa, ki ne smejo čutiti bolečine, tako fizično zatrdevajo.

Spodbujanje $\mathrm{k}$ otrdelosti in hkrati $\mathrm{k}$ večjemu tveganju v življenju je precej usodno za moško populacijo, ki svoje prizadevanje za doseganjem hegemonskega ideala moškosti plača s hitrejšo umrljivostjo (v primerjavi z ženskami). V svojem pregledu zdravja in bolezni zahodnih mož je Will Courtenay pomenljivo zapisal, da moški ravno s tem, ko škodujejo svojemu zdravju (ali recimo - dolžini svojega življenja), pridobivajo oblast in privilegije nad ženskami in drugimi moškimi, ki si škodujejo v manjših merah (Courtenay po Stibbe, 2004, 32)! Courtenayevo povezavo telesne iz-rabljenosti s konvencijami dominantne moškosti (s pozicijo moči) seveda brez težav preslikamo na šport - kjer se telesa uničujejo tem močneje, bliže so utelešenju hegemonske moškosti in bliže, ko se prebijejo k zmagi. V športu je pač »zmaga « cilj, ki opravičuje sredstva. In kaj drugega zmaga pravzaprav pomeni, če ne neposredne dominacije nad nekom, ki postane podrejen?

Športna epistemologija moškosti ne zadeva samo osebnih izkušenj mož, ki se na pot testiranja dominantnosti (pot nadgrajevanja veščin, borbeno-

svojo žensko vlogo izpolnjevale moteče za okolico (npr. kvarile zakonsko zvezo) - v čemer je uvidel upor proti pasivni vlogi, ki jim jo je namenjala družba.

12 V svoji raziskavi nasilja med hokejisti je Nick Pappas ugotovil, da se trenerji raje ogrejejo za borbenega hokejista kot za dobrega drsalca, enako pa reagirajo tudi gledalci, ki močno spodbujajo pretepe (posebno tiste iz »samoobrambe«). Velik del pritiska na hokejiste prihaja tudi iz lastnih vrst, saj si član ekipe, ki ne premore poguma za nasilno konfrontacijo $\mathrm{z}$ »izzivalcem « (in torej za tveganje lastnega zdravja za dobro skupine), ne zasluži biti član ekipe (Pappas, McKenry in Skilken Catlett, 2004, 300-304). 
sti in mišične mase) podajo poklicno. Velika večina moških lastne športne izkušnje iz otroštva ${ }^{13} \mathrm{v}$ odrasli dobi dopolni, vendar predvsem $\mathrm{z}$ gledanjem drugih eksemplaričnih teles. Večina teles, ki redno požira moškostne vrednote športa, ob tem "pasivno " greje naslanjače in električne kable. Športni programi televizijskim gledalcem, zavito v celofan "zabave«, sporočajo, da je "pravi moški močan, trd, agresiven in kar je najpomembneje, še vedno zmagovalec v svetu, ki je še vedno moški« (Messner, Hunt in Dunbar po Stibbe, 2004, 48).

Praksa gledanja športa je ena redkih, kjer lahko moški brez občutka slabe vesti uživajo ob pogledu na drugo moško telo. Užitka seveda ne interpretirajo kot erotičnega, saj institucija športnega komentarja gledalčevo pozornost spretno usmeri na izvedbo in tehnične detajle, gibajoče se krasno telo pa prej postane subjekt identifikacije kot objekt seksualne želje. Prestopiti prag identifikacije in tovarištva je v športu - vsaj dokler je ta zvezan s procesiranjem hegemonske moškosti, ki prisega na heteronormativnost - v glavnem hudo prepovedano. Kot pravi Gary Whannell, se pogledu gledalcev (pogledu, ki je lahko privilegij in hkrati instrument moči (Adams, 2005, 68), pogledu, ki objektivira (Irigaray po Copeland, 1993, 139)) športniki trudijo izogniti $s$ »kulturo trdosti« oziroma $\mathrm{z}$ »mišično neranljivostjo« (v Adams, 2005, 69).

Mogoče je reči, da se v pogledu v veliki meri skriva odgovor na vprašanje, zakaj so »najmožatejši« športi tudi najbolj agresivni. Iz česar pa lahko sledi tudi sklep, da je šport arena, ki je, v Adlerjevem (1989) besednjaku, dobesedno namenjena "protestiranju moškosti«. Saj, ali šport brez gledalcev sploh obstaja? Zmage pred gledalci so po pravilu daleč bolj adrenalinske in nasilne (v športih, ki stavijo na merjenje telesnih zmogljivosti, pa npr. rekordne), kot bi bile brez njih. Kot se tako zdi, se prav z izgubo določene avtonomije - s pogledom drugega - in s prizadevanjem po pridobitvi izgubljene moči (ki jo v družbi enačijo z moškostjo) konvencije hegemonske moškosti ne le »kompenzirajo«, pač pa tudi ustvarjajo.

13 Športna aktivnost v šolah (ki je v zadnjih dveh desetletjih vsaj po večini evropskega kontinenta, vključno s Slovenijo, nadomestila pouk »telesne vzgoje«) je po eni strani dejavnost, ki v instrumentalno (tako rekoč »moško «) rabo telesa uvaja tako fante kot dekleta, po drugi strani pa ostaja prav tista šolska dejavnost, ki najočitneje vleče črto med spoloma in $\mathrm{z}$ ločenimi praksami kreira in inkarnira tako blagoslovljene moške kot zaželene ženske lastnosti. 
Če se v odnosu med gledalci in športniki z agresijo slednjih premaguje pogled, ki je lahko erotičen, športniki možnost homoerotike med svojimi vrstami uspešno preganjajo skozi diskurze in prakse, ki objektivirajo ženske. Objektivacije so lahko precej krute, nasilje fizično, vendar družba seksistične izpade športnikov rada tolerira (Pappas, McKerny in Skilken Catlett, 2004, 306-307) - saj gre za vzore moškosti oziroma ideale, h katerim sloni večina (ki se sama seveda ne spusti tako daleč). Tozadevno je zelo zanimiva raziskava, ki jo je med univerzitetnimi kolegi opravila Sharon Bird (1996) in z njo zelo jasno pokazala na seksualno popredmetenje žensk v družabnih pogovorih moških visoko izobraženih krogov. O ženskah (kot še o športu, politiki, alkoholu in o poslih) je sredi homosocialne družbe $e^{14}$ pač veliko lažje razpravljati kot o »sebi«. ${ }^{15}$ Razgaliti se drugemu moškemu pomeni pristati na ravni ranljivosti. Ta pa lahko nevarno vodi v izgubo lastne dominantnosti ali - v intimnost.

Šport moškim idealno omogoča, da drug drugega ne obsipavajo s čustvi »toplega« značaja - vsaj ne neposredno. Omogoča jim, da si medsebojno naklonjenost izražajo na podlagi (skupne) ljubezni do zmage, ekipe ali kar do države, ki jo zastopajo. ${ }^{16} \mathrm{Ni}$ nenavadno, da so v času med svetovnima vojnama šport v Evropi imenovali kar za »vojno v miru« (Mosse, 2005, 260). Saj so se tudi v vojnah, na podlagi skupnega ideala, za »višje« namene (za dobro nacije) zbirali moški, ki so skupaj izpolnjevali ne le naloge, delili hrano, pijačo in mesta v jarkih, pač pa so v vojni izkusili tudi nekaj, kar se v

14 »Homosocialnost« je termin, ki označuje neseksualno privlačnost, ki jo eden do drugega čutijo pripadniki istega spola (moški do moških oziroma ženske do žensk). Homosocialnost s pomočjo ostre segregacije v družbenih institucijah promovira distinkcije med moškimi in ženskami (Bird, 1996, 121).

15 Sharon je med »svojimi« moškimi opazila, da je med njimi zelo nezaželeno govoriti o občutkih in govoricah. »Čustvena odcepitev« - je poimenovala vedenje, ki gradi na opozicioniranju ženskam - materam. V diskurzu opazovancev je "pravi moški« predstavljal tistega moškega, ki se zmore s težavami spopasti sam in je torej »neodvisen« (Bird, 1996, 125-127). Morda bi prav v takšnih nazorih lahko koreninila "pogosta moška praksa« (kot jo je opazil Martin Pumphrey), da notranje konflikte postavljajo ven, na druge osebe in jih rešujejo tam (v Burt, 1995, 17).

$16 \mathrm{~V}$ mislih imam predavanje Ulle-Britt Lilleås na 2. nordijski konferenci o moških in moškostih v Turkuju 2006, ki je s svojo sociološko raziskavo med poklicnimi rokometaši pokazala, da je športna arena lahko tudi arena za izražanje globokih čustev, ki jih ti moški zunaj športnih dvoran v glavnem ne kažejo. Poleg agresije in čustev sovraštva so tu prisotni tudi močni izrazi ljubezni - izraženi npr. celo s poljubom na usta. 
hegemonskem diskurzu dihotomnega pogleda na spol nikakor ne postavlja v moško domeno: skrb za drugega. Topla skrb se je po I. svetovni vojni (kot je proces v Nemčiji analiziral Mosse) prevedla v sinonim tovarištva, ki je še okrepil ideal medmoških odnosov kot čistih, neseksualnih, nadtelesnih - $\mathrm{s}$ koristjo za vso nacijo. In kot so v vojni moški (paradoksalno) izkušali izraze medsebojne naklonjenosti, tako se je šport razvil v področje, kjer si smejo moški na podlagi skupnih idealov podeljevati izraze zaupanja in sprejemanja - seveda posredno. Medmoška ljubezen (pa s tem ne mislim samo erotike, mislim na intimno priznavanje drugega, ki ga v predojdipski fazi otroku telesi mati) je tolikšen tabu, da v vsakdanu potrebuje posrednike. Ideja oziroma dogodek »zmage« lahko med športniki (pa tudi med gledalci) uspešno zmanjša razumsko in celo telesno distanco, ki je norma. Žal se to zgodi na način, ki nekoga $\mathrm{v}$ procesu potlači.

Homosocialnih moških (z)druže(va)nj, kot je športno, je v moderni družbi še kar nekaj (politika, gospodarstvo, vojska ipd.), vendar se ob vseh nima smisla podrobneje ustavljati. Kar sledi, bo skok k hegemonski praksi, ki najmočneje simbolizira telesenje drugega dela kompetentnosti za patriarhalno dominanco - veščinskosti, in ki po mojem mnenju tudi občutno marginalizira moško plešoče telo.

\section{Tehnika in moški}

Sherry Ortner je leta 1974 opisala patriarhat tako, da je moški odnos do žensk izenačila $\mathrm{z}$ vladavino kulture nad naravo. Sledi vprašanje: katero je najočitnejše polje kultivacije, polje, s katerim kultura nadvlada naravo? In odgovor se glasi: tehnika oziroma tehnologija. ${ }^{17}$

17 Po Velikem slovarju tujk beseda »tehnika« (ki izhaja iz grške besede tehne - spretnost, umetnost, (praktična) veščina), pokriva področja, kot so: 1) ustaljeni način izvajanja kakega opravila, obvladovanje metod in sredstev, potrebnih za dosego kakega cilja; 2) širok izbor sredstev in naprav, ki se uporabljajo za proizvodnjo materialnih dobrin; 3) veda, ki se s tem ukvarja. Beseda »tehnologija" stoji na pomenih, kot so: 1) veda o pridobivanju surovin, obdelavi, predelavi od začetka do končnega stanja; 2 ) skupek postopkov od pridobivanja surovin do izdelave končnega izdelka (dani primeri: kemijska tehnologija, tehnologija lesa, prodajna tehnologija) (Veliki slovar tujk, 2002, 1142). Oba koncepta pokrivata proces ustvarjanja kulture iz narave oziroma oba označujeta neko veščinsko delo, ki vključuje tudi 
Da enačenje tehniki podrejene narave in žensk ni kritika enodnevnica, je v osemdesetih potrjevala Cynthia Cockburn, ki je pisala, da je »moška polastitev mišic, sposobnosti, orodij in strojev /.../ pomemben vir podrejanja žensk« (Cockburn, 1981, 44). To se ujema s kasnejšim teoretiziranjem Boba Connella, ki je med formiranjem dominantnih moškosti skozi zgodovino opazil delitve na moškosti, ki so se in se oblikujejo okoli neposredne dominacije (npr. znotraj korporativnega menedžmenta, vojaškega poveljstva ipd.), in na moškosti, ki se oblikujejo okoli tehničnega znanja (Connell, 1995, 164-181). ${ }^{18}$ Judy Wajcman slednjo skupino moškosti razdeljuje na tiste oblike, ki se zvežejo s fizično žilavostjo in z obvladovanjem mehanskih veščin, ter na tiste moškosti, ki gnezdijo v večji racionalizaciji oziroma specializaciji tehničnega znanja (v Mellström, 2002, 462); kar predstavlja nekakšno delitev telesnega in umskega dela, ki imata $\mathrm{v}$ različnih kulturah različno vrednotenje (v zahodni umsko vsekakor prednjači pred fizičnim), vendar je zanimivo, da, kot v svojih raziskavah ugotavlja antropolog Ulf Mellström (2002; 2004), obe »vrsti« tehnične moškosti temelj svojih, tako ali drugače zavitih vej, koreninita v telesu.

$\mathrm{V}$ splošnem družbenem razumevanju je telo najpogostejša referenčna točka za identificiranje moških identitet. Po eni strani nanj gledajo kot na produkt narave, po drugi pa naj bi imel ta produkt tudi »naravno sposobnost za kulturo«. Kar se sliši - priznajmo si - trapasto, čeprav nič bolj trapasto od prevladujočih diskurzov, ki postavljajo v center te kulture moške, in to na način, da jim pripisujejo "naravno sposobnost za tehnologijo oziroma tehniko«, s katero ženske po pravilu nis(m)o obdarjene (Mellström, 2004, 369). Vez med moškimi in tehniko naj bi se pretakala po skupnih žilah - s čimer se po svoje strinja tudi Ulf Mellström, vendar z razliko, da on na telo ne gleda kot na stroj in zato tudi vezi med moškimi in tehniko ne vidi kot »danosti«, pač pa kot družbeni »proces«, ki je lahko precej dolgotrajen.

teoretske uvide. Izraz »tehnologija « je v tem smislu novodobna tavtologija »tehnike«, ki skuša telesnemu znanju dodati komponento »razuma « $(\log o s)$. Osebno se torej bolj nagibam $\mathrm{k}$ rabi besede »tehnika«.

18 Formacijski skupini si kdaj pa kdaj sicer pogledata iz oči v oči, vendar njun odnos v glavnem zaznamuje avra toplega sodelovanja. 
Mellströmovo delo razkriva skupne značilnosti moških iz različnih kultur, ki si s tehniko (različnih ravni) služijo kruh. V spominih tako malezijskih mehanikov kot švedskih inženirjev zgodnje telesne izkušnje s tehniko zasedajo posebna mesta:

»Čutno zadovoljstvo in močna čustva, ki so izšla iz interakcije s stroji, so izrednega pomena za samozavest in veselje tako pri mehanikih kot inženirjih /.../ in takšno zadovoljstvo in čustva kulturno kodirajo kot moška.» (Mellström, 2004, 371-372)

Že takoj v začetku so ti fantje z brkljanjem po aparatih ali pa s čiščenjem orodja očetov prejeli tudi informacijo o svoji moški identiteti. Pozitivna telesna izkušnja se je s časom zlila v telesno urjenje (v glavnem dolgotrajen proces ponavljanja za vzorom in ponavljanja lastnih dejanj), z njim pa so se telesa naučila, kako iz umetnih mehanizmov razbrati sporočila in kako na njih izvesti pomenske fizične spremembe.

Občutek »obvladovanja materije« se pri tehničnem delu nikoli ne utrjuje zgolj z verbalno komunikacijo in gledanjem. Prav tako so pomembni tipanje, poslušanje, vonj, pa tudi lasten mišični napor, kar seveda vodi v večjo osebno vključenost oziroma, kot pravi Douglas Harper: »Pridobitev kinestetičnega čuta zmanjša prepad med subjektom-delavcem in objektomdelom« (Harper po Mellström, 2004, 374; kurziv Z. P.). Omenjeni »kinestetični čut « (ki ga družba postavlja med posesti moškosti) komunikacijo med subjekti in objekti toliko poenoti, da se lahko, kot so Mellströmu poročali malezijski mehaniki in švedski inženirji, nekateri stroji in orodja spremenijo $\mathrm{v}$ podaljšek posameznikovih praks.

"Moškost« čuta za tehniko iz specifične kinestetike izloča ženske. ${ }^{19} \mathrm{~Pa}-$ radoksalno so ženske v svetu tehnike kljub temu prisotne, in sicer na simbolni ravni: tehniki in tehnologi svoje stroje - »mašine« - pogosto naslavljajo z ženskimi atributi. So one. Ne zgodi se redko, da mašina transgresira v subjektovo »najboljšo prijateljico« in da postane rama za velik in raznolik

19 Govorim o hegemonskih predstavah. Da je realnost drugačna, je v osemdesetih letih preteklega stoletja pisala Cynthia Cockburn, ki je pokazala, da so ženske prav toliko uporabnice tehnologije kot moški in so ob tem tudi prav toliko fizično (u)sposob(lje)ne. Razlika obstaja $\mathrm{v}$ tem, da tehnologija moškim predstavlja drugačno identifikacijsko točko v življenju kot ženskam (v Mellström, 2004, 369-370). 
spekter moških čustev, zgodi pa se tudi, da se ob frekventnem (telesnem) ukvarjanju $\mathrm{z}$ mašino in ob vestni skrbi zanjo med »njo« in »njim « zgodi ljubezen. V zgrajenem prostoru intime mašine brez problemov poosebijo lastnosti, ki si jih moški želijo, da bi jih izražale njihove ljubljene osebe (Mellström, 2002, 473-475).

Mašina lahko postane podaljšava sebstva, lahko dobi ženske atribute, a v obeh primerih moški zasede funkcijo, ki se imenuje »določanje (njene) usode«. Dominiranje nad stroji in njihova feminizacija pomagata ohranjati heteronormativnost znotraj tehničarskega ceha, hkrati pa v spolni sliki tega sveta reproducirata homosocialnost. Moško dominantnost torej. Kje vse to najbolj razveljavi moškost telesu, ki svojo kinestetiko uri v plesu?

Videti je, da je za moške najsprejemljivejše, če čustev oziroma svojega "notranjega « stanja ne delijo z drugimi moškimi v svoji okolici, pač pa da z njimi delijo skupno izkušnjo intime s predmeti. Tako imajo (spet) posrednika, ki uspešno preprečuje neposredno moško-moško intimnost. In prav predmetni posrednik čustev je po mojem mnenju tisti element, ki močno pripomore k razveljavljanju moškega baletnega telesa. Zakaj bi bilo sicer na področju umetnosti - področju »umetelnega izražanja« - najmanj moškostnega prestiža dodeljenega prav plesalcem, ki so praktično edini, ki za svoje izražanje ne potrebujejo predmetov? Brez besed, brez glasbenega instrumenta (skozi katerega lahko glasbenik javno »joka«, »se jezi« in »se smeji«), brez platna in barv. Plesalec se $v$ času urjenja svojega telesa prav tako poda na razvijanje videnja, slišanja, na pot mišičnega napora, analiziranja in $\check{c} u$ tenja, kot mehanik, pa vendar ob tem ne razvije zavezanega odnosa do neke umetne tvarine, pač pa se dihotomija subjekt/objekt podre v odnosu do lastnega telesa (govorim o delitvi um/telo)! In seveda tudi do teles drugih. Manko predmeta, ki bi dokazoval racionalnost in torej "trd(n)ost « čustvujočega osebka, moškega stane moškosti.

\section{Meje hibridnosti}

Teorija moškostih in hegemonske moškosti (v veliki meri delo Raewyn Connell - kot se pravzaprav zdaj imenuje sociologinja, še ne dolgo nazaj sociolog R(obert) W(illiam) alias Bob Connell), je bila odločilna za kritično 
pristopanje $\mathrm{k}$ moški moči in $\mathrm{k}$ hkratni senzibilnosti za raznolikost moških življenj in patriarhalnih koristi. Hkrati je pomembno pomagala pri etabliranju specifičnega področja raziskav, ki so moške zbezale iz spolizacijske sence (ob čemer so se ob sociološkem vodstvu začeli združevati pristopi različnih družboslovnih in humanističnih disciplin), in ga danes krovno velikokrat zaznamuje ime »kritične raziskave moških" (critical studies on men) (podrobnosti glej v Hearn, 2004). Zdaj, ko se omenjenim raziskavam ponekod že ni več potrebno boriti za priznanje, čas zahteva, da se konceptualni okviri prečistijo - pravi Jeff Hearn, ki prav tako sodi med vidnejše snovalce omenjenega polja.

Teorija moškostih in hegemonske moškosti je potrebna pretresa, saj se družba ves čas spreminja ( $\mathrm{z}$ njo moškosti), moškim pa kljub temu vedno nekako »uspe«, da ostanejo na dominantni poziciji, česar teorija moškosti do zdaj še ni uspela razložiti in je vprašanje, če to sploh lahko stori. Poleg tega nastali opus raziskav po svoje celo reproducira spolno dihotomijo, ki jo ves čas neposredno ali posredno napada, trdi Marie Nordberg (2003 in 2006).

Problematičen je sam koncept moškosti. Kot je zapisal sociolog John MacInnes, oba termina - moškost in ženskost - premočno zamejujeta, saj sta po definiciji vezana na patriarhat in modernost (in torej na nacionalnost - kot piše Hearn, 2004, 64). Gre za koncepta 19. stoletja, ki ju je ustvarila liberalna in moderna družba kot odgovor na obstoj spolne neenakosti. MacInnes o moškosti meni tudi, da je dvoumna, saj po eni strani nekako lebdi v družbi (jo lahko telesi kdorkoli), po drugi strani pa se veže na moško telo. Ves čas se bolj kot od žensk pričakuje, da jo bodo izvajali moški, kar pomeni, da jo še vedno vidijo kot naravnejše vezano na moške:

»Razlike med moškimi in ženskami, ki so jih v predmodernem patriarhalnem kontekstu lahko opredeljevali kot naravno determinirane (rezultat biološkega spola), so morale zdaj postati družbeno producirane - kot moškost in ženskost (rezultat kulturnega spola).« (MacInnes po Nordberg, 2003, 3)

Vezanje moškosti (pojmovanih kot specifičnih osebnostnih lastnosti) na moške je kamen spotike, s katerim novi kritični akademiki reproducirajo spolno dihotomnost. Marie Nordberg se slabosti prav dobro zaveda in za potrebe lastnih raziskav namesto "moškosti« rajši uporablja koncept, ki ga je v queerovskih raziskavah ob koncu devetdesetih let uvedla Judith Halberstam. 
Kot ponazarjajo analize Lise Adkins, ljudje sodobnega časa vse bolj telesijo spolno fleksibilnost, kakršno od njih zahteva trg delovne sile. »Novi načini izvajanja spola konstruirajo nove hierarhije, pogosto skrite pod domnevno spolno enakost." (Nordberg, 2003, 6) Kot pravi Adkinsonova, moške na modernem trgu delovne sile spodbujajo, da naj bodo družabni, empatični, neavtoritarni in da uporabljajo čustva - kar se po konsenzu kodira kot ženske karakteristike - od žensk pa po drugi strani pričakujejo, da se bodo v precejšnjem številu okoliščin vedle moško. Pri tem naj bi moško izvajanje ženskosti veliko bolje nagrajevali od ženskega izvajanja moškosti (recept za uspešno reprodukcijo patriarhata, torej), vendar Marie Nordberg opozarja, da v tovrstnih sodbah ne gre pretiravati, saj nekateri načini ženskega bivanja še vedno nikakor ne sodijo v sprejemljivi repertoar moškega vedenja. Androginost je v današnjem času zaželena karakteristika, vendar ima meje, ki so pomenljive.

Po terenu med moškimi, ki se udejstvujejo na "ženskih" področjih (predšolska vzgoja, frizerstvo in zdravstvena oskrba ${ }^{20}$ ), je Nordbergova dekonstruirala govor o ženskosti, kot so koncept uporabljali možje. Ugotovila je, da je bila ženskost kot »osebnostna lastnost « pri njih pogosto zaželena, medtem ko so ženskost kot telesno govorico, specifično oblačenje in kot druge navezave na stereotip "poženščenega homoseksualnega moškega« istočasno konstruirali kot problematične. Moški delavci so lahko integrirali ženskost, vezano na »ženski način bivanja«, a ženskost, ki naj bi bila po njihovem dojemanju povezana s homoseksualnostjo, jim ni predstavljala sprejemljivega telesenja. Marie Nordberg je lahko ugotovila, da je zaradi heteroseksualne hegemonije ena oblika ženskosti v moškem izražanju bolj problematična od drugih (Nordberg, 2003, 12). Kategorija moškega je tista vsakdanja in vztrajna stvar, ki najbolj zadošča kriterijem koncepta hegemonije (Hearn, 2004). Kategoriji moškega in ženske pa domala neločljivo prepaja kategorija heteroseksualnosti.

$20 \mathrm{~V}$ mislih imam seveda poklic »Zdravstvenega tehnika« - po domače »medicinske sestre«. Že igra besed $\mathrm{v}$ slovenščini dovolj pove o spoliziranosti poklica in specifičnih besed: medtem, ko nam gre ženska oblika besede »tehnik« (»tehnica«?) po navadi težko z jezika, »medicinski brat « sicer tu in tam komu pade iz ust, a v večini ni termin, ki bi ga zdravstveni diskurzi priznavali. 
Čisto na koncu eksplicitnega pisanja o spolih in spolnosti naj se zazrem v plesno dvorano - ki je iniciator vsega do sedaj napletenega. Moški plesalci, kot kaže, družbene kode ženskosti telesijo do mere, ki prestopa videz heteroseksualnosti.

\section{Moško plešoče telo}

Homoseksualnost (ta precej mlada mestna identiteta) se je $\mathrm{z}$ odrskim plesom na zahodu zvezala v začetku 20. stoletja, ko je pariške odre prevzela skupina Ballets Russes, ki je balet vrnila v sodobnost in v moško telo. Da so ga ruski baletniki »vrnili« plesni umetnosti, pomeni, da je moralo omenjeno telo prej »izginiti«. Kar nas pripelje do idej 19. stoletja, brez katerih ne morem nadaljevati.

Romantika predstavlja čas, ko so podobe moških teles - tistih bolj razgaljenih - izginile iz umetnosti, kot sta slikarstvo in kiparstvo. Istočasno se je moška (mestna) moda zreducirala na "sivo « črnino in konfliktno je postalo vse, kar je dišalo po spektaklu moškega telesa (Burt, 1995, 13). ${ }^{21}$ George Mosse sicer ugotavlja, da so se podobe moških teles z 19. stoletjem znašle v nadčutnem, simbolnem oziroma nacionalno-ikonografskem svetu, vendar njegove ugotovitve ne pomenijo drugega kot potrditev tabuiziranega statusa omenjenih teles (statusa, ki ga poleg nečistih konotacij vedno obdaja tudi sij svetosti). Kot piše Ramsay Burt, je prav tabu na spektakel moškega telesa ogromno prispeval k izginotju moških nog z baletnih odrov v 19. stoletju: telo kot točka pogleda se nekako ni več moglo pobahati s svojo moškostjo. Kar mi v misli pripelje del Foucaultovega pisanja o oblasti - ki pravi, da se oblast po eni strani (po gledališko) uprizarja in razkazuje, po drugi pa svojemu pogledu izpostavlja telesa drugih, podrejenih (Dolar, 1991). ${ }^{22}$

21 Beseda "spektakel« izhaja iz latinskega samostalnika spectaculum - pogled, prizor - oziroma iz glagola spectare - gledati, opazovati, raziskovati. V slovenščini izraz najpogosteje uporabljamo kot sinonim za dogodek, ki vzbudi veliko (vizualne) pozornosti (Veliki slovar tujk, 2002, 1077).

22 Foucault dva principa sicer razporeja $\mathrm{v}$ različni fazi zgodovine. Medtem ko javna obglavljanja (kot zadnja instanca odstranjevanja iz družbenega pogleda) in šopirjenje dvora predstavljata prvo omenjeno manifestacijo oblasti - vezano na čas fevdalizma, zapiranje sistemskih tujkov (ne več njihovo izločevanje, pač pa izpostavljanje pogledu kontrole), predstavlja dru- 
Balet je pred 19. stoletjem zelo uspešno služil kot promocija in šopirjenje oblasti, telešene $\mathrm{v}$ dvoru, ${ }^{23} \mathrm{~s}$ prehodom $\mathrm{v}$ dobo dominacije (trgovskega) meščanstva, pa se je (telesno) razkazovanje očitno preneslo drugam - sama menim, da v institucijo športa. Kot sem omenjala, je danes šport arena za kreiranje in razkazovanje hegemonske moškosti par excellence, in glede na to, da telesi tako dominantnost dominantne opozicijske spolne kategorije kot dominantno ideologijo kapitalističnega (meščanskega) sistema - tekmovalnost - lahko rečem, da šport je tisto področje, kjer se oblast dobesedno razkazuje in uprizarja (zdrava, močna in lepa, kjer oči ne zaznajo hendikepa). ${ }^{24}$ Balet je v sozvočju $z$ dogajanjem izgubil ceno (se pravi: svoje zveze z oblastjo). Postal je celo prostor nadzora, saj so se, izpostavljene pogledu moških, na odru znašle ženske, ki niso bile tudi katerekoli ženske, pač pa tiste nekonformistke, ki so si življenja začrtale stran od domačih ognjišč, popolne denarne odvisnosti in telesne zastraženosti. Pogled iz avditorija in pogled za odrom sta emancipacijo oklestila na nadzor. Če se zdaj vrnem na Burtovo ugotovitev, da je »dejavnost«, ki je v 19. stoletju močno zdesetkala moški ples, slišala na ime "prepoved spektakla moškega telesa«, s svojim nadaljevanjem po Foucaultu lahko dodam, da se v tem kažeta predvsem meščanski prevzem baletne umetnosti in moški protinapad na žensko emancipacijo v 19. stoletju.

Poleg tega je bilo na baletu tudi nekaj konkretnih partikularnosti, ki so neposredno zbadale hegemonijo moških - takrat teleseno v meščanskem razredu. Moške vloge v baletih 19. stoletja so po večini poosebljale »dvorne funkcionarje« oziroma so bile reminiscenca na moškega danseur noble iz

gi nivo oblasti - pri Foucaultu 19. stoletje. Kakorkoli omenjeno delitev priznamo za resnično, pogled na ritualno dogajanje v sodobnosti prav tako lahko potrjuje prvo in drugo obliko delovanja oblasti. Oblast se še vedno samopromocijsko izpostavlja družbenemu pogledu in ob tem iz vidnega polja čisti nekompetentneže, po drugi strani pa prav »taista " oblast s svojimi očmi tudi nadzoruje. Gre za dva principa, ki po mojem težko predstavljata razvojni fazi v zgodovini človeštva, pač pa se skozi čas morda spreminjata v svoji intenzivnosti in mediaciji.

23 To si poglej npr. v Lawson (1973) ali Au (1995).

24 Telesna promocija oblasti je bila bojda veliko kristalnejša v času množičnih - najprej nacionalističnih, potem pa nacističnih in komunističnih - gimnastičnih manifestacij po Evropi (za primer glej Roubal, 2003), vendar prav gotovo ne do mere, kot je to danes mogoče videti $\mathrm{z}$ distance, saj vsaka oblast pač deluje le toliko časa, kolikor jo "podložniki« jemljejo za samoumevno, za normalo. 
predromantičnega obdobja, kar meščanom, ki so se zgražali nad pokvarjeno aristokracijo, seveda ni dišalo po možatem (»človeškem«) idealu. Poleg tega je iz pisanja takratnih »kritikov« (še posebno Gautierja) mogoče razbrati, da je moško telo na odru vse preveč spominjalo na telo delavca (opisi ogromnih, robustnih teles $\mathrm{v}$ nasprotju $\mathrm{z}$ drobnimi, lahkotnimi in okretnimi vilinskimi, so moško telo na odru označevali za precej grozljivo prikazen). Kot je seveda jasno, delavski razred prav tako ni sodil med priljubljene teme za meje občutljivega meščanskega razreda (Burt, 1995, 25-27). Tako so se torej daleč pred kamnom homoseksualnosti na moška pleča v baletu obesili predsodki, ki so jih označili za napačen element $v$ umetnosti (Mary Douglas (1993) bi jim rekla packa na sistemu) in za nekaj grdega. Prav tako "grda« homoseksualnost se je plesalcem le odlično podala. In z dejanskimi homoseksualnimi primeri v 20. stoletju so se homofobne strukture samo izrazile v polni luči.

Ples kot tak je v 19. stoletju padel najnižje med umetnostmi (celo v sklopu bohemskih - gledaliških). Burt pravi, da gibanje po odru očitno ni veljalo za ugledno sredstvo (samo)izražanja - kar, če spomnim na svoje minulo pisanje o hegemonski možatosti v izražanju s predmeti, za 19. stoletje, ko je družba na novo doživela tehnološki prelom in vodstvo industrije, zveni precej logično. Moški brez prisotnosti (takrat vzpostavljenih) »kultivacijskih materialov« niso bili pravi moški. Telesna tehnika, ki je prej kot spremembi »zunanjega« materiala namenjena telesu samemu, je morala nekako izpasti iz kulture in se znajti v predkulturnem. Če upoštevamo psihoanalizo Nancy Chodorow $(1974 ; 1997)$, ples kot neverbalna komunikacija močno asociira na prvo komunikacijo, ki jo otrok telesi ob materi, ko njuna vez (in otrokova identifikacija) še ni očetovsko prekinjena. Predojdipska faza je potem tista moška skrb, ki mora biti v kulturah, kjer se spola opozicijsko ločujeta, zatrta. Lacanovska psihoanaliza nam s svojega zornega kota pravzaprav ponuja tudi generalno razlago za nizek status plesne umetnosti na Zahodu sploh: kajti ples kot telesna/gibalna in torej neverbalna dejavnost $\mathrm{v}$ moško dominirajoči in spolno dihotomni kulturi (v kateri je - po principih psihoanalize - moški vzpostavitelj besednega (abstraktnega/oddaljenega) jezika in s tem kulture) tipično zgrmi po vrednostni lestvici navzdol (Burt, 1995, 14-16).

Seveda ne smemo pozabiti še zadnjega večjega razloga, zaradi katerega je moško telo, ki je od začetkov v 16. stoletju dalje z institucijo plesa potrje- 
valo svojo družbeno moč, v 19. stoletju izginilo z baletnih odrov (in je balet alias odrski ples hkrati izgubil ceno). Moški baletni plesalec se je prenevarno približal krhki meji med homosocialnostjo in homoseksualnostjo. Ob pogledu na moškega plesalca so se gledalci (po večini moški) počutili neprijetno. Kar je popolnoma razumljivo, saj se je pogled iz avditorija dejansko velikokrat nadaljeval po zasebnih rezidencah nastopajočih (plesalk) in njihovih bogatih ljubiteljev (nizka plača je plesalke v to prisilila, glej Adair (1992)), kar pomeni, da se je v pogledu znašla (ali pa razkrila) neka erotična senzibilnost, ki je moški moškim takrat že niso več smeli kazati. Moški, ki občuduje delo drugega moškega, je klasična enota, ki omogoča moško homosocialnost in s tem patriarhat. Pa vendar po 19. stoletju to občudovanje ni smelo več vsebovati seksualnih elementov. ${ }^{25}$ In plesni nastop za razliko od športnega ne pozna institucije komentarja, ki bi gledalski pozornosti onemogočila objektivacijo.

\section{Telešenje $\mathbf{v}$ plesni dvorani}

$S$ prakso in v telesni areni se gradi subjektivnost - ves čas. Pri tem telesa niso le objekti, pač pa so tudi tvorci procesa. Natančneje, kot je v začetku devetdesetih dvajsetega stoletja opozarjal antropolog Thomas Csordas (s pretresom Merleau-Pontyjevega in Bourdieujevega pogleda na telo in kulturo), sta človekova percepcija in praksa - kot dva kulturna temelja - že od vsega začetka telešeni (1990). Poglejmo si nekaj telesitvenih primerov iz vsakdana baletnih plesalcev. ${ }^{26}$

$\mathrm{V}$ večjih baletnih šolah pouk baleta navadno poteka ločeno za dekleta in fante. Plesalec, ki ga imenujem Maarten, mi je povedal, da so njega balet vedno poučevali moški pedagogi, medtem ko so dekleta na šoli poučevale ženske: "In potem se resnično naučiš, kot naj bi tvoj spol... moral biti. Ne da te učijo, kako se gibati bolj moško..., to kar postaně̌. " Ker imaš moškega vzornika.

25 Več o tem v Pezdir (2008).

26 Kar sledi, je fragment etnografskih zapisov, ki so nastali po antropološkem opazovanju in intervjuvanju baletnih plesalcev SNG Opera in balet Ljubljana med oktobrom 2005 in marcem 2006. Več v Pezdir (2008). 
Seveda ne gre kar samo od sebe, balet je neprikrita disciplina telesa. Je dolgotrajni trening, s katerim se telesita natančnost in vztrajnost - bi rekla Lejla, ki mi je povedala, da so ji nenehni »boji s svojim telesom « in ukvarjanje $\mathrm{z}$ detajli pri baletu dali neko disciplino oziroma vztrajnost in pozornost na detajle, ki se poznata tudi zunaj baletnega sveta. Gre za veliko mero discipline, ki baletno gramatiko in zgoraj omenjeni perceptivni kvaliteti telesi na prav poseben način - Mihaly bi mu rekel »kultiviran«.

Za razliko od športne dejavnosti poučevanje tu ne poteka $\mathrm{z}$ motivacijo zmage, pač pa balet še vedno v glavnem velja za področje lepote in človekovega (čustvenega in čutnega) izražanja. Na področju baleta je zelo pomembno, kako se izvajajo koraki, ne samo kateri ti so. Ta kako seveda ni popolnoma prepuščen posameznikom, ampak v njem odzvanjajo konceptualizacije lepega skozi zahodno moderno zgodovino.

Mihaly mi je o motivaciji za balet ob svojih začetkih povedal npr. tole: »Bil sem ponosen, da sem bil drugačen od vseh ... Baletna šola je zelo čista, ljudje tam so zelo prijazni, lepo so oblečeni, izgledajo dobro, dekleta, fantje, vsi izgledajo dobro, vsi so prijazni ... "Veliko bolje seveda kot umazana šola, v katero je hodil do svojega dvanajstega leta (država: Madžarska; režim: realsocialistični). Baletna šola je bila tista, ki je bila »elegantna«, kar pomeni, da je Mihaly že v povezavi s prostorom in ljudmi, ki so ga obkrožali, pri sebi telesil občutek večvrednosti. Takšni občutki niti meni niti komu drugemu, ki ga v slovenskem baletnem svetu bolje poznam, med šolanjem niso bili tuji.

Kot osnovnošolka sem sama na svoje sošolce gledala kot na nezrele in kričave plebejce - moj odmik nad njihova obzorja pa je bil po eni strani seveda moja obramba (obramba pred norčevanjem iz mojih - njim slabo poznanih - aktivnosti). Ne bi rada lastne izkušnje posplošila na vse druge plesalce, vendar je res, da smo se pri baletu mimogrede učili tudi vedenja. Prijaznosti in spoštovanja. Nasilnih izpadov se tu ne tolerira (kot se jih v športni areni).

Kljub temu, da se pomeni in vrednotenja baleta ustvarjajo vedno znova, pri tem vedno znova dialoško sodeluje tudi zgodovinski kup pomenov, ki so ples na zahodu povzdignili v »civilizacijski dosežek « oziroma v »umetnost«. Ples (balet) je na evropskih dvorih sprva predstavljal odlično 
tehniko za telesenje nenasilne komunikacije, pa tudi za telesenje razredne večvrednosti. Specifično samoobvladovanje telesa naj bi, kot je v šestnajstem stoletju pisal Castiglione, odlikovalo dobrega dvorjana, ki je v svojih lepih dejavnostih utelešal sprezzaturo, kar pa ni pomenilo drugega kot delovati nonšalantno oziroma $\mathrm{z}$ videzom lahkotnosti prekrivati trud, ki je sicer asociiral na spodnje razrede (Filmer, 1999, 6). Iskanje lahkotnega videza, ki prekrije težko pridelano virtuoznost, se zdi sestavni del umetniškega diskurza, ki ga je kot takega $\mathrm{v}$ odnosu do popularnega in ljudskega diskurza v glasbi prepoznal tudi Simon Frith (1996). Tak pogled v analizah plesa večina piscev seveda določa »klasičnemu baletu«, je pa potrebno poudariti, da gre res za zgodovinsko določeni romantični in klasični balet, ${ }^{27}$ saj se je že s Posvetitvijo pomladi Vaclava Nižinskega tež(av)nost dogodila tudi meščanskemu odru. ${ }^{28}$ Dobrih sto let nazaj. In realizirala se je tudi zato, ker je sledila vzoru šamanskih ritualov in v trudu ter težnosti zaznala dodatne načine za doseganje transcendentalnega stanja - ki je druga značilnost umetnosti (nadaljevanje po Frithu). Transcendentalna izkušnja v umetnosti ostaja aktualna vse do danes, o čemer so na različne načine poročali tudi moji sogovorniki. Je užitek prepuščanja »višjim silam« (telesu, adrenalinu, gledalski energiji ipd.), potem ko je telo samo za to naredilo ogromno.

Med plesom telo, ki je hkrati neodtujeni jaz, obvladuje prostor in čas. »Pri plesu, pesmi in glasbi gre kljub različnim gibalnim in zvokovnim strukturam bolj za kultivacijo intuitivnega, neeksplicitnega in neizrazljivega, za spoznavanje, izražanje in podoživljanje ritma človekove biti v sve$\mathrm{tu}$, kot pa za iskanje neke dokončne, $\mathrm{z}$ besedami izražene resnice,« dalje meni antropolog Borut Telban (2002, 28-29). Čeprav ples lahko omogoča različne vrste transcedentalnosti (psiho-fizično, nad-subjektivno) ali telesi družbene norme ( $\mathrm{z}$ besedami npr. imenovane spol), to še ne pomeni, da se

27 Prvega uvrščamo v prvo polovico 19. stoletja, drugega pa v drugo polovico 19. stoletja.

28 Posvetitev pomladi, za katero je glasbo napisal Igor Stravinski, je premiero doživela v Parizu leta 1913. Temo predstave so zaznamovala stara slovanska plemena, delovanje množic in žrtvovanje izbranega dekleta, kar je Nižinski skoreografiral z zoperstavitvijo dotedanjim baletnim kodom. Stravinskijeva partitura in Nižinskijeva koreografija sta povzročili škandal, tako, da se do danes koreografija ni ohranila. Po rekonstrukcijah sodeč je bila Nižinskijeva koreografija prej kot "podaljšek « telesu »ovira" - v svoji nesimetrični postavitvi telesa in razkrivanju težnosti (gl. npr. Les Printemps du Sacre, 1993). 
plesalci s tem ukvarjajo na verbalno-artikulativni ravni. Telešenje je predvsem izkustvena reč.

V institucionaliziranem plesnem svetu, kakršen je balet danes, popolnoma brez objektivacijskih besed seveda ne gre. Ko sem v SNG opera in balet Ljubljana opazovala vaje za predstavo, sta koreograf in asistent kar precej razlagala pomene gibov, ki naj bi jih plesalci posvojili v lastna telesa. Kljub temu sem imela sama občutek, da so razlage prihajale predvsem naknadno, kot interpretacijska pomoč za hitrejšo telesno posvojitev, in ne kot ideje, ki bi gibe tudi ustvarile. Kasneje mi je koreograf Mihaly to tudi potrdil, rekoč: več ubesedenih razlogov za izvedbo specifičnih gibov kot jih bo plesalec spoznal, prej bo lahko posvojil koreografovo zgodbo in jo (po najboljšem možnem scenariju) tudi nadgradil. Mihaly mi je povedal, da se njemu impulz za postavitev baleta zgodi bodisi v dobri literaturi (zgodbi), za katero potem poišče glasbo, ali pa v glasbi, za katero poišče zgodbo, vendar pa se mu gibi sami ob tem rodijo $» \mathrm{z}$ improvizacijo « - iz telesa. In nobenega celovečernega baleta do sedaj še ni naredil drugače, kot skozi oblike in občutja lastnega telesa. $\mathrm{V}$ njegovem primeru lahko zelo jasno in glasno govorim o telesnem tvorcu (agentu), ki na podlagi občutenj (percepcij) začetnega impulza (glasbe ali zgodbe) oblikuje vsebino baletne predstave. Kar pa počne tudi Ajda, ki jo v glavnem »inspirira glasba«, iz katere potem sledijo telesni gibi, odnosi med telesi in zgodba (elementi, ki potem drug drugega motivirajo dalje), ali pa koreografinja, s katero sem enkrat sodelovala sama, ki je ne zmotivirata niti obstoječa glasba niti zgodba, pač pa trenutna atmosfera med plesalci in njeno lastno telesno počutje. Vsak plesni ustvarjalec si najde neki svoj impulz, motivacijo. A vsebina privre skozi njegovo oziroma njeno lastno telo. $\mathrm{V}$ tem primeru lahko govorimo o telesu kot agentu.

Koliko tvornosti pri vsem skupaj odigrajo telesa plesalcev, je v veliki meri odvisno od volje in načina dela koreografa. Nekateri koreografi pustijo svojim plesalcem več, drugi pa manj eksperimentalnega prostora v določeni vlogi. Vsekakor telesa izvedejo tisto, kar zmorejo sama. Meja tvornosti se v najbolj surovi obliki pozna v telesnih poškodbah. 


\section{Sklepne misli}

Vrnimo se k spoznanju, da moška sebstva preko tehnike in športa telesijo silo in veščost, $\mathrm{s}$ pomočjo katerih se patriarhalni sistem $\mathrm{v}$ glavnem še vedno močno obnavlja. Kakšno sliko družbe nam takšne telesne prakse moških naslikajo?

"Govorimo o problemih nasilja na splošno, o kriminalu in mladinskih tolpah, ne da bi specifizirali, da $\mathrm{v}$ večini te statistike reprezentirajo fantje in moški. Pričakovana življenjska doba moških je nižja od ženske, moški imajo več nesreč, moški polnijo zapore in najvišje kriminalne statistike in moški so tisti, ki skoraj ekskluzivno sprejemajo odločitve, ki vodijo v oborožene spopade in vojne.« (Breines, Connell in Eide, 1999, 12)

Avtorji zgornjega citata se v članku Moške vloge in moškosti v perspektivi kulture miru ('Male Roles and Masculinities in the Perspectives of a Culture of Peace', 1999) resno sprašujejo, če deklice socializiramo v kulturo miru, dečke pa v kulturo vojne. Primerov ni iskati samo v intimnih prostorih družin, pač pa tudi v nacionalnih institucijah, kakršna je npr. šola.

Šola je arena, ki ima na procese oblikovanja spoliziranih osebnosti izredno velik pomen. Pri njej ne gre samo za telešenje storilnostnih idealov, pač pa tudi za razvoj dihotomije spolnih identitet, kar se najkristalnejše zrcali prav v urah športne vzgoje. Edini šolski predmet, pri katerem se telo lahko giblje, poteka $\mathrm{v}$ strogi spolni delitvi in $\mathrm{v}$ duhu doseganja točno določenih meril ter tekmovanja. Stran od kompleksnosti in pluralnosti teles. Glede na ugotovitve, da je naše telo tudi naša percepcija, tako v zaznavnem kot spominskem smislu (Csordas, 1990; Anttila, 2004) in da je v bistvu medij, skozi katerega se dobesedno (z)gradimo in komuniciramo dalje, šolsko favoriziranje »umskega dela " nad »telesnim « na eni strani in stiskanje preostalega telesnega izraza v okvire tekme in sužnosti tehničnim pripomočkom (štoparici, metrom ipd.) na drugi strani, odraščajočemu potencialu sprememb povzroča neprecenljivo škodo. Devetdeseta 20. stoletja so "telesno vzgojo« v šolah zamenjala $s$ »športno«. Zakaj ne bi mogli namesto v/zga(n)janja »boja proti sovražniku« v šole uvesti npr. tehnike za »spoznavanje lastnih meja in meja drugih« ter namesto »telovadbe« uvesti ples? 
Hudo je, da se ples v šoli pojavi šele kot terapija za zdravljenje nasilnega vedenja. ${ }^{29}$ Zakaj se ta "preventiva ne bi mogla uvesti kar v sistem sam?

Moški plesalci, ki sem jih spoznavala na terenu, so se na eni ravni kar precej identificirali s hegemonskimi diskurzi (diskurzom športa, diskurzom tehnike), vendar so lahko kljub temu ob situacijah, ki so se zdele »varne«, zaživeli marsikatero od praks, ki nikakor ne sodijo v polje patriarhalno uspešnih moškosti. Najpomembneje se mi je pri njih zdelo to, da pri svojem umetniškem prizadevanju sodelujejo $\mathrm{z}$ ženskami, ${ }^{30} \mathrm{da}$ njihov vsakdan poteka v fizični bližini tako žensk kot drugih moških, ${ }^{31}$ ter da za potrebe svojega poklica uporabljajo celoten izrazni korpus, ki ga imajo na voljo - svoje telo, $s$ čuti in občutki vred.

Telešenje v plesu je lahko telešenje svobode, meni Eeva Anttila (2004). Vendar tu ne sme iti za tisto svobodo, ki smo jo z veseljem posvojili v liberalnem kapitalizmu, s sloganom »uresniči svoje sanje« (»in pojdi preko trupel«). Kot že dostikrat skozi moderno zgodovino zahoda, mora pač tudi tokrat pojem »svobode« doživeti svojo redefinicijo (podobnosti s prizadevanjem po redefiniciji hegemonske moškosti na zahodu so tu izjemne!): ozavestiti bo potrebno, da kot družbena bitja sanje uresničujemo šele v komunikaciji z drugimi ljudmi (Anttila, 2004, 25). In kot rečeno, učenje tovrstne svobode (oziroma svetu prijaznejše moškosti, dodajam sama) Anttila prepoznava $\mathrm{v}$ telesni udeležbi v plesu:

»Učenje plesa se lahko razume kot praksa svobode, ko plešoči subjekt, oziroma telo/subjekt, med doseganjem telesnih in izraznih veščin, ostaja odprt in fleksibilen v smislu njenih/njegovih osebnih plesalskih kvalitet in v smislu njenega/njegovega koncipiranja teh kvalitet. Učenje plesa kot prakse svobode

29 V ZDA so se po vse več nasilnih tragedijah, kakršno je bilo npr. streljanje v šoli Columbine v Littletonu, v novem tisočletju šole začele zanimati za "preventivne " programe za zmanjšanje nasilnega vedenja, kjer so se zaenkrat kot zelo uspešni izkazali plesni terapevti/terapevtinje (za primer gl. Koshland in Wilson B. Wittaker, 2004).

30 Raewyn Connell je slednje označila za izredno pomemben faktor uspešnega izvajanja politike spreminjanja moškosti (Connell, 1995, 237).

31 Avstralski psihoterapevt Kerry Cronan pri svojem terapevtskem delu z moškimi npr. ugotavlja, da tabu bližine oziroma zaupnega stika med moškimi (tabu, ki ga poganja kolesje homofobije, velja pa samo za moške, ženske ga vztrajno presegajo) povzroča tako frustracije, bolezni kot moško pehanje za uspehi oziroma nezaupno tekmovalnost $\mathrm{v}$ odnosu $\mathrm{z}$ drugimi moškimi (Cronan, 2005). 
pomeni tudi to, da se plesalec/plesalka krepi, se pravi, da je sposoben/sposobna izbirati in se med plesom ravnati po lastnih izbirah in da so te izbire in akcije zavestne in odgovorne v odnosu do drugih. Telesna občutljivost, združena $\mathrm{s}$ premišljenostjo lahko uenoti telo in um $\mathrm{v}$ času in prostoru in ustvari prostor za simultana srečevanja lastnega sebstva $\mathrm{z}$ drugimi.« (Anttila, 2004, 58.)

Naj gre za »klasični balet« (po pristopu, ki ga je preizkusila Paula Salosaari (2001)) ali »sodobni ples", ples je lahko tvorno telesno delo, ob katerem se zrušijo dualnosti um/telo, razum/čustvo ${ }^{32}$ in subjekt/objekt, kot je o telešenju sklenil Thomas Csordas (1990). Ciklično sodelovanje v tvornih telesnih procesih spreminja sebstvo, spreminja spolnost in spreminja spol.

\section{VIRI IN LITERATURA}

Adair, Christy, 1992, Women and Dance: Sylphs and Sirens. London: Macmillan.

Adams, Mary Louise, 2005'»Death to the Prancing Prince«: Effeminacy, Sport Discourses and the Salvation of Men's Dancing. Body and Society 11(4): 63-86.

Adler, Alfred, 1989, Individualna psihologija. Novi Sad: Matica srpska.

Anttila, Eeva, 2004, 'Dance Learning as Practice of Freedom.' V: The Same Difference?: Ethical and Political Perspectives on Dance. Leena Rouhiainen, Eeva Anttila, Soili Hämäläinen in Teija Löjtönen, ur. Helsinki: Theatre Academy: 19-62.

Au, Susan, 1995 (1988) Ballet and Modern Dance. London, New York: Thames and Hudson.

32 Čustvo, ki ga sistem šolstva npr. precej potiska vstran, gre pa za (kot je pojav opisala Michelle Rosaldo) nekakšno kognicijo, ki za razliko od »hladnega razuma« vsebuje večji občutek zavezanosti, vključenosti (Csordas, 1990, 37). Brez čustev procesi identifikacije bolj težko nastopijo (s katerimi procesi empatije) in prav isto lahko zatrdimo za nastop osebne zavzetosti oziroma politične akcije. 
Bird, Sharon, 1996, 'Welcome to the Men's Club: Homosociality and the Maintenance of Hegemonic Masculinity.' Gender and Society 10(2): 120-132.

Breines, Ingeborg, Robert Connell in Ingrid Eide, 1999, 'Male Roles and Masculinities in the Perspective of a Culture of Peace.' Mannsforskning 2: 8-14.

Burt, Ramsay, 1995, The Male Dancer: Bodies, Spectacle, Sexualities. London, New York: Routledge.

Butler, Judith, 1997, 'Excerpt from »Introduction« to Bodies That Matter.' V: The Gender/Sexuality Reader. Roger N. Lancaster in Micaela di Leonardo, ur. New York, London: Routledge: 531-542.

Chodorow, Nancy, 1974, 'Family Structure and Feminine Personality' V: Woman, Culture and Society. Michelle Zimbalist Rosaldo in Louise Lamphere, ur. Stanford: Stanford University: 43-66.

Chodorow, Nancy, 1997 (1978), 'The Psychodynamics of the Family.' V: The Second Wave: A Reader in Feminist Theory. Linda J. Nicholson, ur. New York, London: Routledge: 181-197.

Cockburn, Cynthia, 1981, 'The Material of Male Power. Feminist Review 9: 41-58.

Connell, R. W., 1982, 'Class, Patriarchy, and Sartre's Theory of Practice.' Theory and Society 11(3): 305-320.

Connell, R. W., 1995, Masculinities. Cambridge: Polity Press.

Connell, R. W., 2002, Gender. Cambridge: Polity Press.

Copeland, Roger, 1993, 'Dance, Feminism and the Critique of the Visual.' V: Dance, Gender and Culture. Helen Thomas, ur. London: Macmillan: 139-150.

Cronan, Kerry R., 2005, 'What is Homophobia?: Men and Vulnerability.' Referat na konferenci International Association for Relationship Research. Julij 2005, Vitoria, Brazilija.

Csordas, Thomas J., 1990, 'Embodiment as a Paradigm for Anthropology'. Ethos 18(1): 5-47. 
Dolar, Mladen, 1991'Spremna beseda.' V: Michel Foucault, Vednost - oblast subjekt. Ljubljana: Krt: vii-Xxxv.

Douglas, Mary, 1993 (1966), Čisto i opasno. Beograd: Plato.

Gender/Sexuality Reade, The, 1997, The Gender/Sexuality Reader. New York, London: Routledge.

Filmer, Paul, 1999, 'Embodiment and Civility in Early Modernity: Aspects of Relations between Dance, the Body and Sociocultural Change.' Body \& Society 5(1): 1-16.

Foucault, Michel, 1993 (1984), Zgodovina seksualnosti 3: Skrb zase. Ljubljana: ŠKUC.

Foucault, Michel, 1998 (1984), Zgodovina seksualnosti 2: Uporaba ugodij. Ljubljana: ŠKUC.

Foucault, Michel, 2000 (1976), Zgodovina seksualnosti 1: Volja do znanja. Ljubljana: ŠKUC.

Frith, Simon, 1996, Performing Rites: On the Value of Popular Music. Oxford: Oxford University.

Hearn, Jeff, 2004'From Hegemonic Masculinity to the Hegemony of Men.' Feminist Theory 5(1): 49-72.

Jefferson, Tony, 1997, 'Muscle, »Hard Men« and »Iron« Mike Tyson: Reflections on Desire, Anxiety and the Embodiment of Masculinity' Body and Society 4(1): 77-98.

Koshland, Lynn in J. Wilson B. Wittaker, 2004, 'PEACE Through Dance/Movement: Evaluating a Violence Prevention Program.' American Journal of Dance Therapy 26(2): 69-90.

Laland, Kevin N. in Gillian G. Brown, 2002, Sense and Nonsense: Evolutionary Perspectives on Human Behaviour. Oxford: Oxford University.

Lawson, Joan, 1973, A History of Ballet and Its Makers. London: Dance Books.

Mellström, Ulf, 2002, 'Patriarchal Machines and Masculine Embodiment.' Science, Technology and Human Values 27(4): 460-478. 
Mellström, Ulf, 2004, 'Machines and Masculine Subjectivity: Technology as an Integral Part of Men's Life Experience.' Men and Masculinities 6(4): $368-382$.

Mosse, Georg L., 2005 (1985), Nacionalizem in seksualnost. Ljubljana: ${ }^{*} \mathrm{cf}$.

Muršič, Rajko, 2006, 'Nova paradigma antropologije prostora: Prostorjenje in človeška tvornost.' Glasnik SED 46(3-4): 48-54.

Nordberg, Marie, 2003, 'I'm Not so Masculine. I Try to Use More of My Feminine Sides: Reproductive and Subversive Gender Formations Among Male Swedish Pre-school Teachers, Hairdress and Nurses.' Referat na konferenci Gender and Power in the New Europe. Avgust 2003, Lund, Švedska.

Nordberg, Marie, 2006, '»To Be or Not To Be?«: Some Thoughts On and Research Experience, Bodies and Masculinity.' Referat na konferenci Nordic Conference on Men and Masculinities: Experiences of Men. Maj 2006, Turku, Finska.

Ortner, Sherry B., 1974, 'Is Female to Male as Nature is to Culture?' V: Women, Culture, and Society. Michelle Zimbalist Rosaldo in Louise Lamphere, ur. Stanford: Stanford University: 67-87.

Pappas, Nick T., Patrick McKenry in Beth Skilken Catlett, 2004, 'Athlete Agression on the Rink and off the Ice: Athlete Violence and Agression in Hockey and Interpersonal Relationships.' Men and Masculinities 6(3): 291-312.

Pezdir, Zala, 2008, Moški in balet - misija mogoče? Maribor: Ruslica.

Printemps du Sacre, Les, 1993, 'Les Printemps du Sacre.' Dokumentarni film. Jacques Malaterre, režija. La Sept/Arte in Telmondis.

Redman, Peter, 2001, 'The Discipline of Love: Negotiation and Regulation in Boys' Performance of a Romance-Based Heterosexual Masculinity'. Men and Masculinities 4(2): 186-200.

Roubal, Petr, 2001, 'Politics of Gymnastics: Mass Gymnastic Displays under Communism in Central and Eastern Europe.' Body and Society 9(2): $1-25$. 
Rubin, Gayle, 1997 (1975), 'The Traffic in Women: Notes on the »Political Economy " of Sex.' V: The Second Wave: A Reader in Feminist Theory. Linda J. Nicholson, ur. New York, London: Routledge: 27-62.

Salosaari, Paula, 2001, Multiple Embodiment in Classical Ballet: Educating the Dancer as an Agent of Change in the Cultural Evolution of Ballet. Helsinki: Theatre Academy.

Snoj, Marko, 1997, Slovenski etimološki slovar. Ljubljana: Mladinska knjiga.

Sperling, Susan, 1997, 'Baboons with Briefcases vs. Langurs with Lipstick: Feminism and Functionalism in Primate Studies.' V: The Gender/Sexuality Reader. Roger N. Lancaster in Micaela di Leonardo, ur. New York, London: Routledge: 249-264.

Stibbe, Arran, 2004, 'Health and the Social Construction of Masculinity in Men's Health Magazine.' Men and Masculinities 7(1): 31-51.

Telban, Borut, 2002, 'Ples kulture in kultura plesa: Primeri iz Nove Gvineje in širšega Pacifika.' Poligrafi 7 (27-28): 7-30.

Veliki slovar tujk, 2002, Veliki slovar tujk. Miloš Tavzes, ur. Ljubljana: Cankarjeva založba.

West, Candace in Don H. Zimmerman, 1987, 'Doing Gender.' Gender and Society 1(2): 125-151.

Wittig, Monique, 1997 (1981), 'One is Not Born a Woman.' V: The Second Wave: A Reader in Feminist Theory. Linda J. Nicholson, ur. New York, London: Routledge: 265-271.

http://social.chass.ncsu.edu/jouvert/v2il/Connell.htm

http://www.bruehlmeier.info/adler.htm

http://www.beepworld.de/members79/izbran/adler.htm 


\title{
THE EMBODIMENT OF MASCULINITY: FROM TECHNIQUES TO DANCE
}

Keywords: body, embodiment, men, masculinities, sport, techniques, theater dance

\begin{abstract}
This article surveys a palette of various theories of the body - from biology to cultural determinism - and it anchors itself in the concepts of body agency and the gendered body. The gender theme reduces its focus to the male body and those practices that continuously confirm this body's masculinity; special attention is dedicated to the embodiment of masculinities in sports and techniques. An examination of dance follows. To reveal why the masculinity of dancing men is so often questioned in Western culture, certain aspects of Western theater dance history are discussed and there is a brief commentary on the SNG Opera and Ballet. This article reveals where embodiment techniques of hegemonic masculinities restrain the dancing male body, and it points to their wider social consequences, which the author believes are worth changing.
\end{abstract}

